\title{
THE MODEL OF DESCRIPTION OF EXTRACTION OF URANIUM-235 AND URANIUM-238 ISOTOPES COMPLEXES IN A SUPERCRITICAL CARBON DIOXIDE LAYER HEATED FROM BELLOW
}

\author{
B.V. Borts ${ }^{1}$, S.F. Skoromnaya ${ }^{1}$, V.I. Tkachenko ${ }^{1,2}$ \\ ${ }^{1}$ National Science Center "Kharkov Institute of Physics and Technology”, \\ Kharkiv, Ukraine; \\ ${ }^{2}$ V.N. Karazin Kharkiv National University, Kharkiv, Ukraine \\ E-mail: tkachenko@kipt.kharkov.ua
}

\begin{abstract}
The models and analytical solutions for description of the extraction of ${ }^{235} \mathrm{U}$ and ${ }^{238} \mathrm{U}$ isotopes complexes in case of availability of water microdrops located both in a uniform temperature field and in a non-uniform temperature field of the heated from bellow horizontal layer of the supercritical carbon dioxide are suggested. It has been indicated that in a uniform temperature field the efficiency of supercritical fluid extraction with carbon dioxide complexes of uranium isotopes reaches a maximum at the limit of water solubility in supercritical carbon dioxide. Theoretical calculations have demonstrated that the maximum concentration of ${ }^{235} \mathrm{U}$ isotope complexes heated from below in a supercritical carbon dioxide layer reaches $1.2 \%$ and is observed near the lower layer boundary. The procedure for supercritical fluid extraction with carbon dioxide is described, in which the concentration of ${ }^{235} \mathrm{U}$ isotope complexes in the supercritical fluid will be higher than the natural one.
\end{abstract}

\section{INTRODUCTION}

It is known that water plays an important role in supercritical fluid extraction with carbon dioxide (SFE$\mathrm{CO}_{2}$ ). The availability of macroquantities of added water facilitates the extraction of metal complexes into supercritical carbon dioxide $\left(\mathrm{SC}-\mathrm{CO}_{2}\right)[1]$ or liquid $\mathrm{CO}_{2}$ [2].

With no water the processes of extraction of metal complexes are missing at all [3].

Due to significant effect of the added water on the processes of SFE- $\mathrm{CO}_{2}$, it should be noted that the molar fraction of water dissolved in $\mathrm{SC}-\mathrm{CO}_{2}$ at a temperature of $40{ }^{\circ} \mathrm{C}$ and an almost twofold increase in pressure (from 10 to $20 \mathrm{MPa}$ ) changes 1.36 times from 0.00428 to $0.0058[4,5]$.

Thus, proceeding from $[4,5]$ it is possible to determine the amount of water dissolved in $\mathrm{SC}-\mathrm{CO}_{2}$ which is required for carrying out SFE- $\mathrm{CO}_{2}$, i.e. excess water does not enter $\mathrm{SC}-\mathrm{CO}_{2}$ and does not participate in the extraction.

In addition, it is shown in [6] that the full use of water dissolved in $\mathrm{SC}-\mathrm{CO}_{2}$ also provides efficient SFE$\mathrm{CO}_{2}$. It is shown here that the dependence of SFE-CO efficiency has a peak nature: with an increase in the amount of added water the extraction efficiency increases and reaches its maximum value when the amount of water is equal to the limit of its solubility in $\mathrm{SC}-\mathrm{CO}_{2}$. Further increase in the amount of added water leads to decreasing $\mathrm{SFE}-\mathrm{CO}_{2}$ efficiency. The determined dependence of the extraction efficiency on the amount of added water was physically substantiated using the principle of detailed balance formulated by A. Einstein through the example of two-level systems [6]. To describe the solubility of uranium complexes in $\mathrm{SC}-\mathrm{CO}_{2}$ concentrated in water microdrops together with pure water microdrops, a double two-level model is proposed. The results obtained from this model are in quantitative agreement with the experimental data, which indicates the adequacy of the proposed model.

Since the chemistry of metal complexing is the same for all its isotopes, it is of interest to study the CSFE$\mathrm{CO}_{2}$ complexes of metal isotopes. This study is legitimate due to the difference in water microdrops containing isotope complexes in terms of mass and probability of induced transitions between energy levels.

The aim of this work is to study the application of two-level systems to describe the spatially uniform distribution of complexes of ${ }^{235} \mathrm{U}$ and ${ }^{238} \mathrm{U}$ isotopes in $\mathrm{SC}-\mathrm{CO}_{2}$ layer heated from below.

MODEL OF DESCRIPTION OF EXTRA-
CTION OF ${ }^{235}$ U AND ${ }^{238}$ U ISOTOPES
COMPLEXES IN A LAYER OF SUPER-
CRITICAL CARBON DIOXIDE IN THE
PRESENCE OF WATER MICRODROPS
IN A UNIFORM TEMPERATURE FIELD

Let us consider $\mathrm{SFE}-\mathrm{CO}_{2}$ of uranium complexes under the condition of maintaining a constant temperature of $\mathrm{SC}-\mathrm{CO}_{2}$ in its entire volume. In this case, there is no convective heat and mass transfer in the supercritical fluid and the probabilities of induced transitions are constant values independent of temperature.

It is known that the most notable quantities out of 16 isotopes of natural uranium are isotopes of ${ }^{238} \mathrm{U}$ $(99.275 \%)$ and ${ }^{235} U(0.720 \%)$ [7]. Therefore, we will consider uranium consisting of these two isotopes.

To describe $\mathrm{SFE}-\mathrm{CO}_{2}$ of uranium complexes consisting of ${ }^{235} \mathrm{U}$ and ${ }^{238} \mathrm{U}$ isotopes in the presence of water microdrops in a uniform temperature field the results of previous experimental and theoretical studies presented in [6] are applicable.

However, now to describe the SFE- $\mathrm{CO}_{2}$ extraction 
of the uranium complex consisting of ${ }^{238} U$ and ${ }^{235} U$ isotopes in the presence of water we will use a triple two-level system, the scheme of which is shown in Fig. 1. In this figure the index $\alpha$ takes the values $b, \kappa 1$ or $\kappa 2$, which means water drops with uranyl nitrate complex based on ${ }^{238} \mathrm{U}+\mathrm{TBP}$ isotope or water drops with uranyl nitrate complex based on ${ }^{235} \mathrm{U}+\mathrm{TBP}$ isotope, respectively.

We believe that formation of particles of types $\kappa 1$ and $\kappa 2$ at level 2 is explained by the selective accumulation of uranyl nitrate complexes based on ${ }^{238} \mathrm{U}+\mathrm{TBP}$ isotope and uranyl nitrate complexes based on ${ }^{235} \mathrm{U}+\mathrm{TBP}$ isotope in different water microdrops. This selectivity can be explained by the formation of associates in water microdroplets [6] and is indirectly confirmed in experiments [8]. Thus, based on the above, it can be argued that at level 2 the relative content of uranium isotopes in particles of types $\kappa 1$ and $\kappa 2$ should correspond to the natural one.

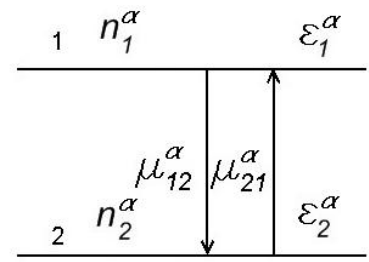

Fig. 1. Scheme $\alpha$ of two-level systems with populations $n_{1}^{\alpha}, n_{2}^{\alpha}$.

The arrows show the induced transitions between energy levels with the corresponding probabilities:

$$
\mu_{12}^{\alpha} \text {-down; } \mu_{21}^{\alpha}-\text { up; where } \mu_{12}^{\alpha}=\mu_{21}^{\alpha}
$$

As before [6], we believe that dissolved $\mathrm{SC}-\mathrm{CO}_{2}$ microdrops of types $B, \kappa 1$ or $\kappa 2$ are accumulated at level 1. At level 2 microdroplets of types $6, \kappa 1$ or $\kappa 2$ are concentrated, which held by a filter paper. We believe that the following relationship between the free energies of the levels is valid: $\varepsilon_{1}^{\beta} \approx \varepsilon_{1}^{\kappa 1} \approx \varepsilon_{1}^{\kappa 2}>\varepsilon_{2}^{\beta} \approx \varepsilon_{2}^{\kappa 1} \approx \varepsilon_{2}^{\kappa 2}$.

Induced transitions of microdrops of types $\beta, \kappa 1$ or $\kappa 2$ from level 2 to level 1 are independent and competing processes.

The independence of the induced transitions means no effect of two-level systems on one another.

The competition between the processes of induced transitions is due to the fact that the volume of level 1 is limited by the value $0.5 \cdot n_{2}^{8}(0)[6]$.

The isotopes ${ }^{238} \mathrm{U}$ and ${ }^{235} \mathrm{U}$ have very similar chemical properties. Therefore, they form the same chemical compound $\mathrm{UO}_{2}\left(\mathrm{NO}_{3}\right)_{2}$, which by addition of two TBP molecules forms a uranium complex $\mathrm{UO}_{2}\left(\mathrm{NO}_{3}\right)_{2} \cdot 2$ ТБФ high soluble in $\mathrm{SC}-\mathrm{CO}_{2}$ [3], where ТБФ - tributyl phosphate. Selective release of uranium complexes with different isotopes by water microdrops and formation of microdrops of types $\kappa 1$ and $\kappa 2$ is apparently associated with formation of various supramolecular assemblies from these two isotopes [9] which arise as a result of spontaneous association [10, 11].
The probabilities of induced transitions of microdrops of types $\kappa 1$ and $\kappa 2$ [6] are higher than those of water microdrops $8\left(\mu_{21}^{\kappa 1}, \mu_{21}^{\kappa 2}>\mu_{12}^{B}\right)$. However, the latter will also fill the upper energy level 1 although slower while limiting the volume of possible location of microdrops $\kappa 1$ and $\kappa 2$.

The initial equations for describing the induced processes in independent two-level systems presented in Fig. 1 have the form [6]:

$$
\begin{gathered}
\left(n_{1}^{\alpha}\right)^{\prime}=\left(n_{2}^{\alpha}-n_{1}^{\alpha}\right) \mu_{12}^{\alpha} N^{\alpha}=-\left(n_{2}^{\alpha}\right)^{\prime}, \\
\left(N^{\alpha}\right)^{\prime}=-\left(n_{2}^{\alpha}-n_{1}^{\alpha}\right) \mu_{12}^{\alpha} N^{\alpha} .
\end{gathered}
$$

The solution of the system of equations (1) gives the following expression for the population of level 1 with microdrops of type $\alpha$ :

$$
n_{1}^{\alpha}(t)=\frac{1}{2} n_{2}^{\alpha}(0)\left(1-\exp \left(-\gamma^{\alpha} t\right)\right)
$$

where $\gamma^{\alpha}=2 N_{0}^{\alpha} \mu_{12}^{\alpha}, N_{0}^{\alpha}=N^{\alpha}(0)-\frac{n_{2}^{\alpha}(0)}{2}, n_{1}^{\alpha}(0)=0$, $N^{\alpha}(0)>>n_{2}^{\alpha}(0)$.

It is easy to show that, when filling the top level, the inequation must be fulfilled:

$$
\sum_{\alpha} n_{2}^{\alpha}(t) \leq \frac{1}{2} \sum_{\alpha} n_{2}^{\alpha}(0) .
$$

The limit ratio is valid for the number of microdrops of types $\kappa 1$ and $\kappa 2$ at level 1:

$$
\left.n_{1}^{\kappa 1}(t)\right|_{t \rightarrow \infty}+\left.n_{1}^{\kappa 2}(t)\right|_{t \rightarrow \infty} \leq \frac{1}{2}\left(n_{2}^{\kappa 1}(0)+n_{2}^{\kappa 2}(0)\right) .
$$

The effect of water microdrops $b$ on the extraction efficiency of microdrops of type $\kappa 1$ can be described in another way. If assume $N^{\kappa 1} \approx N^{\beta}>>1$, then it is easy to show from (9) that the following equation is valid:

$$
\frac{d y}{d x}=\delta_{1} \frac{y}{x}
$$

where $\quad y(t)=n_{2}^{\kappa 1}(t)-n_{1}^{\kappa 1}(t), \quad x(t)=n_{2}^{B}(t)-n_{1}^{B}(t)$, $\delta_{1}=\mu_{12}^{\kappa 1}\left(\mu_{12}^{s}\right)^{-1}>1$.

The solution of equation (5) has the form [6]:

$$
n_{1}^{\kappa 1}(t)=n_{2}^{\kappa 1}(t)-C_{1} \cdot\left|n_{2}^{B}(t)-n_{1}^{B}(t)\right|^{\delta_{1}},
$$

where $\quad C_{1}=n_{2}^{\kappa 1}(0)\left(n_{2}^{B}(0)\right)^{-\delta_{1}}>0-$ the integration constant.

It follows from equations (3), (6) that the efficiency of extraction of microdrops of type $\kappa 1$ in $\mathrm{SC}-\mathrm{CO}_{2}$ decreases with increasing the number of water microdrops 6 .

The same conclusion is valid for microdrops of type $\kappa 2$ with the only difference that constants $C_{1}$ and $\delta_{1}$ in the expression (6) must have different values: $C_{2}=n_{2}^{\kappa 2}(0)\left(n_{2}^{B}(0)\right)^{-\delta_{2}}$ and $\delta_{2}=\mu_{12}^{\kappa 2}\left(\mu_{12}^{B}\right)^{-1}$ respectively.

The conclusion about the power-law dependence of the efficiency of uranium extraction on the water added to $\mathrm{SC}-\mathrm{CO}_{2}$ (5) is qualitatively confirmed by the experimental results [6].

It follows from equation (6) that the extraction 
efficiency of microdrops of type $\kappa 1$, defines as difference in the number of water microdrops at the lower and upper energy levels $\left.\left(n_{2}^{\kappa 1}(t)-n_{1}^{\kappa 1}(t)\right)\right|_{t \rightarrow \infty}$. If we take into account the experimental fact that the extraction efficiency of uranium complexes is a maximum when the amount of water is added to $\mathrm{SC}-\mathrm{CO}_{2}$ which corresponds to its solubility limit [6], then expression (5) can takes the form:

$$
y_{1}(x)=y_{10}-C^{\prime} \cdot\left|x-x_{10}\right|^{\mu_{1}},
$$

where $y_{1}(x)$ - the extract yield $(\%) ; x$ - the amount of added water $(\mu \mathrm{l}) ; x_{10}-$ the limit of water solubility in $\mathrm{SC}-\mathrm{CO}_{2}$.

Optimization (7) according to the experimental data of SFE- $\mathrm{CO}_{2}$ uranium complexes [6] gives the following values of constants: $y_{10}=95.7 ; \quad x_{10}=53.6$; $C^{\prime}=2.2 \cdot 10^{-3} ; \mu_{1}=2.46$. Thus, the theoretical value of the maximum extraction efficiency is about $96 \%$ and corresponds quantitatively to the experimentally measured value.

The obtained results to describe the efficiency of the extraction of microdrops of type $\kappa 1$ can also be used to describe the efficiency of the extraction of microdroplets of type $\kappa 2$, with the only difference being that constants $y_{10} ; C^{\prime} ; \mu_{1}$ in (6) must be replaced by $y_{20} ; C^{\prime \prime} ; \mu_{2}$ respectively. However, to determine these constants it is necessary to carry out a series of experiments to reveal the dependence of the extraction efficiency of microdrops of type $\kappa 2$ on the amount of added water.

Summarizing the results of study of SFE- $\mathrm{CO}_{2}$ complexes of ${ }^{235} \mathrm{U}$ and ${ }^{238} \mathrm{U}$ isotopes in the presence of water microdrops in a uniform temperature field we can draw the following conclusions:

- the use of a triple two-level model SFE- $\mathrm{CO}_{2}$ of ${ }^{235} \mathrm{U}$ and ${ }^{238} \mathrm{U}$ isotopes complexes in the presence of water microdrops in a uniform temperature field has shown that the efficiency of their extraction increases with increasing the amount of water;

- the maximum efficiency of the extraction of complexes of isotopes ${ }^{235} \mathrm{U}$ and ${ }^{238} \mathrm{U}$ in the presence of water microdrops in a uniform temperature field is achieved for the amount of water at the limit of its solubility in $\mathrm{SC}-\mathrm{CO}_{2}$ and under the condition of its complete connection with complexes of uranium isotopes;

- for the amount of water exceeding the solubility limit in $\mathrm{SC}-\mathrm{CO}_{2}$ the efficiency of extraction of ${ }^{235} \mathrm{U}$ and ${ }^{238} \mathrm{U}$ isotopes complexes in the presence of water microdrops in a uniform temperature field decreases.

\section{MODEL OF DESCRIPTION OF EXTRACTION OF ${ }^{235} \mathrm{U}$ AND ${ }^{238}$ U ISOTOPES COMPLEXES IN A LAYER OF SUPERCRITICAL CARBON DIOXIDE HEATED FROM BELLOW IN THE PRESENCE OF WATER MICRODROPS}

Consider a horizontal infinite layer of supercritical fluid bounded from above and below by horizontal planes $z=0$ and $z=h$. The temperature of the upper $T_{1}$ and lower $T_{2}\left(T_{2}>T_{1}\right)$ boundaries of the layer is fixed. The axis $z$ is oriented parallel to the direction of free fall acceleration and temperature rise. For simplicity of calculations we assume that the temperature gradient is constant:

$$
\nabla T=\beta,
$$

where $\beta=\frac{T_{2}-T_{1}}{h}, \vec{e}_{z}-$ unit vector in the direction of the axis $z ; h$ - reactor height.

Heating from below the supercritical fluid layer should lead to convective mass transfer [12] in the form, for example, of a cylindrical convective cell [13], in the center of which the fluid moves from the lower boundary to the upper one with a constant velocity directed against the axis $z$ and equal to $-V$. In addition, the numbers of quanta of fluid $N^{\alpha}$ and the probabilities of induced transitions $\mu_{12}^{\alpha}$ will have a dependence on coordinate $z$ in the uniform temperature field. Under such conditions the equations (1) are transformed to the form:

$$
\begin{gathered}
\frac{\partial n_{1}^{\alpha}}{\partial t}-V \frac{\partial n_{1}^{\alpha}}{\partial z}=\mu_{12}^{\alpha}(z) N^{\alpha}\left(n_{2}^{\alpha}-n_{1}^{\alpha}\right), \\
\frac{\partial n_{2}^{\alpha}}{\partial t}-V \frac{\partial n_{2}^{\alpha}}{\partial z}=-\mu_{12}^{\alpha}(z) N^{\alpha}\left(n_{2}^{\alpha}-n_{1}^{\alpha}\right), \\
\frac{\partial N^{\alpha}}{\partial t}-V \frac{\partial N^{\alpha}}{\partial z}=-\mu_{12}^{\alpha}(z) N^{\alpha}\left(n_{2}^{\alpha}-n_{1}^{\alpha}\right),
\end{gathered}
$$

where index $\alpha$ still takes values $6, \kappa 1, \kappa 2$.

Let us find solutions to equations (8) in the simplest case, when the probabilities of induced transitions $\mu_{12}^{\alpha}$ can be represented as linear functions in coordinate $z$ :

$$
\mu_{12}^{\alpha}(z)=\mu_{12}^{\alpha}(0)\left(1+z \lambda^{\alpha}\right)
$$

where

$$
\lambda^{\alpha}=\left.\frac{1}{\mu_{12}^{\alpha}(0)} \frac{\partial \mu_{12}^{\alpha}(z)}{\partial z}\right|_{z=0}=\left.\frac{\beta}{\mu_{12}^{\alpha}(0)} \frac{\partial \mu_{12}^{\alpha}(z)}{\partial T}\right|_{z=0} .
$$

Let us consider the case when the frequencies of the induced transitions $\mu_{12}^{\alpha}(z)$ are positive functions of coordinate $z$. This requirement imposes the condition that the parameter is positive $\lambda^{\alpha}: \lambda^{\alpha}>0$.

The transition in the original equations (9) to variables $\xi_{\alpha}(z, t)=t\left(1+\lambda_{\alpha} z+\frac{1}{2} \lambda_{\alpha} V t\right)$ transforms them to the form:

$$
\begin{aligned}
& \frac{\partial n_{1}^{\alpha}}{\partial \xi_{\alpha}}=\mu^{\alpha} N^{\alpha}\left(n_{2}^{\alpha}-n_{1}^{\alpha}\right), \\
& \frac{\partial n_{2}^{\alpha}}{\partial \xi_{\alpha}}=-\mu^{\alpha} N^{\alpha}\left(n_{2}^{\alpha}-n_{1}^{\alpha}\right), \\
& \frac{\partial N^{\alpha}}{\partial \xi_{\alpha}}=-\mu^{\alpha} N^{\alpha}\left(n_{2}^{\alpha}-n_{1}^{\alpha}\right),
\end{aligned}
$$

where to simplify writing the notation $\mu^{\alpha}=\mu_{12}^{\alpha}(0)$ was introduced.

The choice of new variables in the form $\xi_{\alpha}(z, t)$ is associated with the fact that it allows to ensure the 
coincidence of level populations at the initial moment of time $(t=0)$ for the system of equations (9) with the initial conditions of the system of equations (11) in new variables $\xi_{\alpha}(z, t)=0$, i.e. $\xi_{\alpha}(z, 0)=0$.

Due to the mutual independence of the systems of equations of two-level systems for particles of type $\alpha$, we will seek their solutions in the corresponding variable $\xi_{\alpha}$.

There are six integrals to find solutions to the system of equations (11):

$$
\begin{gathered}
n_{1}^{\alpha}\left(\xi_{\alpha}\right)+n_{2}^{\alpha}\left(\xi_{\alpha}\right)=n_{10}^{\alpha}+n_{20}^{\alpha} ; \\
N^{\alpha}\left(\xi_{\alpha}\right)+n_{1}^{\alpha}\left(\xi_{\alpha}\right)=N_{0}^{\alpha}+n_{10}^{\alpha},
\end{gathered}
$$

where $n_{10}^{\alpha}=n_{1}^{\alpha}(0), n_{20}^{\alpha}=n_{2}^{\alpha}(0), \quad N_{0}^{\alpha}=N^{\alpha}(0)$ constant values.

Using (12) it is easy to obtain solutions to the system of equations (11):

$$
\begin{gathered}
N^{\alpha}\left(\xi_{\alpha}\right)=\frac{N_{e q}^{\alpha}}{1+\frac{n_{10}^{\alpha}-n_{20}^{\alpha}}{2 N_{0}^{\alpha}} \exp \left(-2 \mu^{\alpha} N_{e q}^{\alpha} \xi_{\alpha}\right)} ; \\
n_{1}^{\alpha}\left(\xi_{\alpha}\right)=\frac{\frac{n_{10}^{\alpha}+n_{20}^{\alpha}}{2}+\frac{n_{10}^{\alpha}-n_{20}^{\alpha}}{2}\left(1+\frac{n_{10}^{\alpha}}{N_{0}^{\alpha}}\right) e^{-2 \mu^{\alpha} N_{e q}^{\alpha} \xi_{\alpha}}}{1+\frac{n_{10}^{\alpha}-n_{20}^{\alpha}}{2 N_{0}^{\alpha}} e^{-2 \mu^{\alpha} N_{e q}^{\alpha} \xi_{\alpha}}} \\
n_{2}^{\alpha}\left(\xi_{\alpha}\right)=n_{10}^{\alpha}+n_{20}^{\alpha}- \\
\frac{n_{10}^{\alpha}+n_{20}^{\alpha}}{2}+\frac{n_{10}^{\alpha}-n_{20}^{\alpha}}{2}\left(1+\frac{n_{10}^{\alpha}}{N_{0}^{\alpha}}\right) \exp \left(-2 \mu^{\alpha} N_{e q}^{\alpha} \xi_{\alpha}\right) \\
-\frac{n_{10}^{\alpha}-n_{20}^{\alpha}}{2 N_{0}^{\alpha}} \exp \left(-2 \mu^{\alpha} N_{e q}^{\alpha} \xi_{\alpha}\right)
\end{gathered}
$$

where $N_{e q}^{\alpha}=N_{0}^{\alpha}+\frac{n_{10}^{\alpha}-n_{20}^{\alpha}}{2}-$ equilibrium numbers of fluid quanta for particles of type $\alpha$.

Let us consider solution (13) for populations of levels 1 and 2 with particles of types $\kappa 1$ and $\kappa 2$ if conditions $n_{10}^{k 1, k 2}=0, N_{0}^{k 1, k 2} \gg n_{2}^{k 1, k 2}$ are satisfied. In this case, solutions (13) can be represented in a simplified form:

$$
\begin{aligned}
& n_{1}^{\alpha}\left(\xi_{\alpha}\right) \approx \frac{n_{20}^{\alpha}}{2}\left(1-\exp \left(-2 \mu^{\alpha} N_{e q}^{\alpha} \xi_{\alpha}\right)\right), \\
& n_{2}^{\alpha}\left(\xi_{\alpha}\right) \approx \frac{n_{20}^{\alpha}}{2}\left(1+\exp \left(-2 \mu^{\alpha} N_{e q}^{\alpha} \xi_{\alpha}\right)\right) .
\end{aligned}
$$

Let us analyze these solutions.

It follows from expressions (15) that at level 2 the number of particles of type $\kappa 2$ at the initial moment of time $t=0$ (here $\xi_{\kappa 2}=0$ ) is equal to $n_{20}^{\kappa 2}$ and must correspond to the natural content: $n_{20}^{\kappa 2} \approx 0.72 \cdot 10^{-2} n_{20}^{\kappa 1}$.

As follows from expressions (14), that at a long extraction time $(t \rightarrow \infty)$, which is equivalent to large values $\xi_{\alpha}$, the number of particles of type $\alpha$ at level 1 tends to half the value of their initial amount at level 2.

At sufficiently short times the expressions (14) show inhomogeneity of distribution of particles of type $\alpha$ along the coordinate $z$.

From (14) we determine the relative concentration of particles of type $\kappa 2$ at level $1(\%)$ :

$$
\begin{aligned}
& C_{1}^{\kappa 2}(z, t)=\frac{n_{1}^{\kappa 2}\left(\xi_{\kappa 2}\right)}{n_{1}^{\kappa 2}\left(\xi_{\kappa 2}\right)+n_{1}^{\kappa 1}\left(\xi_{\kappa 1}\right)} \approx \\
& \approx \frac{0.72}{0.9928} \frac{1-\exp \left(-2 \mu^{\kappa 2} N_{e q}^{\kappa 2} t\left(1+\lambda_{\kappa 2} z+\frac{1}{2} \lambda_{\kappa 2} V t\right)\right)}{1-\exp \left(-2 \mu^{\kappa 1} N_{e q}^{\kappa 1} t\left(1+\lambda_{\kappa 1} z+\frac{1}{2} \lambda_{\kappa 1} V t\right)\right)} .
\end{aligned}
$$

Calculation of concentration (16) at the values of dimensionless parameters $h \mu^{\kappa 1} N_{e q}^{\kappa 1} / V=1.47$, $h \mu^{\kappa 2} N_{e q}^{\kappa 2} / V=0.5, h \lambda_{\kappa 1}=0.04, h \lambda_{\kappa 2}=4.0$ shows that by the moment of time $t^{\kappa 2}=0.046 h / \mathrm{V}$ a certain proportion of particles of type $\kappa 2$ move to level 1 . The dashed line in Fig. 2 shows dependence (16) to the instant of time $t^{\kappa 2}$. The constant $V$ can be determined from the condition that the extraction time is $t^{\kappa 2}=30 \mathrm{~min}$, and the reactor height $-h=21.8$, see [8].

Fig. 2 shows that the theoretical curve $C_{1}^{\kappa 2}\left(z, t^{\kappa 2}\right)$ of concentration of particles of type $\kappa 2$ is in good agreement with the curve $C(z)=0.3+0.85 \frac{z}{h}$ obtained experimentally in [8].

The practical application of the dependence (16) is that at the intermediate stages of SFE- $\mathrm{CO}_{2}$ at $t \leq t^{\kappa 2}$ an increase in the concentration of particles of type $\kappa 2$ relative to the natural one can be achieved in a certain volume of supercritical fluid.

To do this it is necessary at a time instant of SFE$\mathrm{CO}_{2}$ process equal to $t^{\kappa 2}=0.046 h / V$ to discharge the fluid located in the interval $0.6<z / h<1$ into the receiving chamber at atmospheric pressure. In this case, the concentration of particles of type $\kappa 2$ included in the discharged fluid (the composition of these particles includes the isotope of ${ }^{235} \mathrm{U}$ ) will be higher than the natural one.

From (14) it follows that the spatial distribution of particles of type $\kappa 1$ at level 1 at the same time instant $t=t^{\kappa 2}$ is determined by the expression:

$$
C_{1}^{\kappa 1}\left(z, t^{\kappa 2}\right)=\frac{99.28}{2}\left(1-e^{-2 \mu N_{e q}^{\kappa 1} t^{k 2}\left(1+\lambda_{k 1} z+\frac{1}{2} \lambda_{k 1} V^{\kappa^{2}}\right)}\right)
$$

and is of the order of $6.5 \%$.

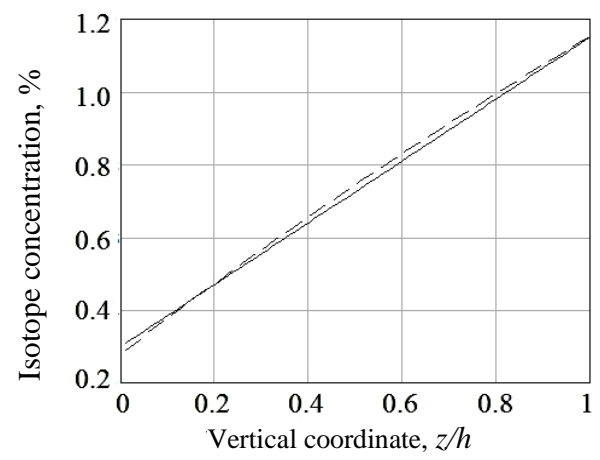

Fig. 2. Concentration of particles of type $\kappa 2-$ $C_{1}^{\kappa 2}\left(z, t^{\kappa 2}\right)$ (dotted line) at level 1 at the time instant $t^{\kappa 2}=0.046 h / V$. Solid line - experiment [8] 
It follows from (16), (17) that at sufficiently short times of SFE- $\mathrm{CO}_{2}$ the inhomogeneity of distribution of particles of type $\alpha$ along the coordinate $Z$ appears. This inhomogeneity of particles distribution along the coordinate at short extraction times makes it possible to estimate the concentration of particles of types $\kappa 1$ and $\kappa 2$.

Thus, based on the results of studying the model proposed in the work for describing SFE-CO complexes of ${ }^{235} \mathrm{U}$ and ${ }^{238} \mathrm{U}$ isotopes in a layer of supercritical carbon dioxide heated from below in the presence of water microdrops, the following conclusions can be drawn:

- a system of equations to describe the change in population levels by particles of type $\alpha$ in a layer of supercritical carbon dioxide heated from below is obtained and its solutions are found;

- it is shown that the frequencies of induced transitions of particles of type $\alpha-\mu_{12}^{\alpha}(z)$ are increasing functions of temperature $T$;

- the phenomenon of competition between particles of type $\alpha$ when they move to level 1is described: more mobile and more numerous particles of type $b$ can move to this level faster, and, thereby, reduce the number of positions to which particles of types $\kappa 1$ or $\kappa 2$ profess;

- it is determined that at long extraction times $(t \rightarrow \infty)$ the number of particles of type $\alpha$ transited to level 1 tends to half the value of their initial amount at level 2;

- at relatively short extraction times $t V / h \approx 0.046$ the dependence of populations of the levels of particles of types $\kappa 1$ and $\kappa 2$ on coordinate $Z$ is manifested;

- the maximum concentration of particles of type $\kappa 2$ reaches $1.2 \%$ and is observed near the heated boundary of the fluid layer;

- the procedure for SFE- $\mathrm{CO}_{2}$ has been determined, in which the concentration of particles of type $\kappa 2$ included in the discharged fluid (the composition of these particles includes the isotope of ${ }^{235} \mathrm{U}$ ) will be higher than the natural.

\section{CONCLUSIONS}

A model for describing SFE- $\mathrm{CO}_{2}$ complexes of ${ }^{235} \mathrm{U}$ and ${ }^{238} \mathrm{U}$ isotopes in a uniform temperature field in the presence of water microdrops is proposed. It is shown within the framework of this model that in a triple twolevel model with a uniform temperature field the extraction efficiency of uranium isotope complexes increases with an increase in the amount of water and reaches a maximum for the amount of water at the limit of its solubility in $\mathrm{SC}-\mathrm{CO}_{2}$ and under the condition of its complete connection with complexes of uranium isotopes. The efficiency of extraction of ${ }^{235} \mathrm{U}$ and ${ }^{238} \mathrm{U}$ isotopes complexes in the presence of water microdrops in a uniform temperature field decreases for an amount of water exceeding the limit of solubility in $\mathrm{SC}-\mathrm{CO}_{2}$.

The multilevel model is proposed and the system of equations for describing SFE- $\mathrm{CO}_{2}$ complexes of isotopes ${ }^{235} \mathrm{U}$ and ${ }^{238} \mathrm{U}$ in a layer of supercritical carbon dioxide heated from below is obtained in this paper also.
The condition when the frequencies of induced transitions of particles of type $\alpha$ are increasing functions of temperature $T$ is considered.

The analytical solutions of the system of equations described the change in the population of level 1 by particles of type $\alpha$ in a layer of supercritical carbon dioxide heated from below are found within the framework of the proposed model.

The phenomenon of competition between the particles of type $\alpha$ during their transition to level 1 is described, which lies in the fact that more mobile and more numerous particles of type $b$ can quickly move to this level and, thereby, reduce the number of positions to which particles of types $\kappa 1$ or $\kappa 2$ can profess.

The analysis of the obtained analytical solutions has shown that at long extraction times $(t \rightarrow \infty)$ the number of particles of type $\alpha$ moved to level 1 tends to half the value of their initial amount at level 2 . At relatively short extraction times $t V / h \approx 0.046$ the dependence of level populations on coordinate $z$ appears.

It is shown that the maximum concentration of a particle of type $\kappa 2$ reaches $1.2 \%$ and is observed near the lower, heated boundary of the fluid layer.

The procedure for SFE- $\mathrm{CO}_{2}$ carrying out when the concentration of particles of type $\kappa 2$ (the composition of these particles includes isotope ${ }^{235} \mathrm{U}$ ) in the supercritical fluid will be higher than the natural one has been determined.

\section{REFERENCES}

1. A. Shadrin, A. Murzin, V. Kamachev, et al. Recovery of Uranium and Transuranics from Stainless Still Surfaces by Subcritical $\mathrm{CO}_{2} / / 7$ th Meeting on Supercritical Fluids, 6-8 December 2000. Antibes. Juan-Les-Pins, France, Proceedings, p. 847.

2. A. Shadrin, A. Murzin, V. Babain. Supercritical Fluid Extraction of Metals by Solutions of Different Complexones in Condensed $\mathrm{CO}_{2} / / 2 n d$ Int. Conf. Super Green, 9-12 November 2003. Japan, Nagoya, p. 105.

3. A.Yu. Shadrin. Ekstraktsiya aktinoidov rastvorami kompleksonov v sverkhkriticheskom i zhidkom diokside ugleroda // Trudy Radiyevogo instituta im. V.G. Khlopina. 2007, t. XII, p. 20 (in Russian).

4. M.B. King, A. Mubarak, J.D. Kim, T.R. Bott. The mutual solubilities of water with supercritical and liquid carbon dioxides // Journal of Supercritical Fluids. 1992, N 5, p. 296-302.

5. A.N. Sabirzyanov, A.P. Il'in, A.R. Akhunov, F.M. Gumerov. Rastvorimost' vody v sverkhkriticheskom diokside ugleroda // High Temperature. 2002, v. 40, N 2, p. 203-208 (in Russian).

6. B.V. Borts, Yu.G. Kazarinov, S.A. Sirenko, S.F. Skoromnaya, V.I. Tkachenko. Vliyaniye vody na effektivnost' sverkhkriticheskoy $\mathrm{SO}_{2}$ ekstraktsii urana iz prirodnykh mineralov // Vestnik KHNU. Seriya fizicheskaya "Yadra, chastitsy, polya". 2012, N 1001, Vyp. 2/54/, p. 125 (in Russian).

7. Khimicheskaya entsiklopediya $v 5$ t.: Tri-yatr / Gl. red.: Zefirov N.S. i dr. M.: "Sov. Entsiklopediya", 1998, 783 p. (in Russian).

8. B.V. Borts, S.F. Skoromnaya, Yu.G. Kazarinov, I.M. Neklyudov, V.I. Tkachenko. Spatial Nonuniform 
Distribution of ${ }^{235} \mathrm{U}$ Isotope at Supercritical Fluid Extraction with Carbon Dioxide in a Gradient Temperature Field // Problems of Atomic Science and Technology. Series "Physics of Radiation Effects and Radiation Materials Science”. 2021, N 5, p. 98.

9. Dj.V. Stid, Dj.L. Atvud. Supramolekulyarnaya himiya. M.: "Akademkniga”, 2007, 898 p. (in Russian).

10. B.V. Borts, Y.G. Kazarinov, P.V. Shakhova, S.F. Skoromnaya, V.I. Tkachenko. Self-assembling associate formation in supercritical carbon dioxide medium under conditions of uranium extraction process // Trudy KHIKH Mezhdunarodnoy konferentsii po fizike radiatsionnykh yavleniy $i$ radiatsionnomu materialovedeniyu. 06-11 sentyabrya 2010. Alushta, Crimea, p. 166 (in Russian).

11. B.V. Borts, S.F. Skoromnaya, V.I. Tkachenko. Formation of associates from nanosized complexes of uranium in the system water - supercritical carbon dioxide // The Journal of KNU, physical series "Nuclei, particles, fields". 2012, issue 3/55/, N 1017, p. 128.

12. S. Chandrasekhar. Hydrodynamic and hydromagnetic stability. 1970, p. 657.

13. B. Borts, Y. Kazarinov, A. Kostikov, V. Tkachenko. Experimental study of liquid movement in free elementary convective cells // Energetika. 2015, v. 61, N 2, p. 45 (in Russian).

Article received 01.10.2021

\title{
МОДЕЛЬ ОПИСАНИЯ ЭКСТРАКЦИИ КОМПЛЕКСОВ ИЗОТОПОВ УРАН-235 И УРАН-238 В ПОДОГРЕВАЕМОМ СНИЗУ СЛОЕ СВЕРХКРИТИЧЕСКОГО ДИОКСИДА УГЛЕРОДА
}

\author{
Б.В. Борц, С.Ф. Скоромная, В.И. Ткаченко
}

Предложены модели и найдены аналитические решения для описания экстракции комплексов изотопов ${ }^{235} \mathrm{U}$ и ${ }^{238} \mathrm{U}$ при наличии микрокапель воды, находящихся как в однородном температурном поле, так и в неоднородном поле температуры подогреваемого снизу слоя сверхкритического диоксида углерода. Показано, что в неоднородном поле температур эффективность сверхкритической флюидной экстракции диоксидом углерода комплексов изотопов урана достигает максимума на пределе растворимости воды в сверхкритическом диоксиде углерода. Теоретическими расчетами показано, что в подогреваемом снизу слое сверхкритического диоксида углерода максимальная концентрация комплексов изотопов ${ }^{235} \mathrm{U}$ достигает величины 1,2\% и наблюдается вблизи нижней границы слоя. Описан порядок проведения сверхкритической флюидной экстракции диоксидом углерода, при котором концентрация комплексов изотопа ${ }^{235} \mathrm{U}$ в сверхкритическом флюиде будет выше природной.

\section{МОДЕЛЬ ОПИСУ ЕКСТРАКЦІЇ КОМПЛЕКСІВ ІЗОТОПІВ УРАН-235 І УРАН-238 У ШАРІ НАДКРИТИЧНОГО ДІОКСИДУ ВУГЛЕЦЮ, ЩО ПІДІГРІВАСТЬСЯ ЗНИЗУ}

\author{
Б.В. Бори, С.Ф. Скоромна, В.І. Ткаченко
}

Запропоновано моделі та знайдено аналітичні розв'язки для опису екстракції комплексів ізотопів ${ }^{235} \mathrm{U} \mathrm{i}$ ${ }^{238} \mathrm{U}$ при наявності мікрокрапель води, що знаходяться як в однорідному температурному полі, так і в неоднорідному температурному полі температур шару надкритичного діоксиду вуглецю, що підігрівається знизу. Показано, що в однорідному полі температур ефективність надкритичної флюїдної екстракції діоксидом вуглецю комплексів ізотопів урану досягає максимуму на межі розчинності води в надкритичному діоксиді вуглецю. Теоретичними розрахунками показано, що максимальна концентрація комплексів ізотопів ${ }^{235} \mathrm{U}$ досягає величини $1,2 \%$ у шарі надкритичного діоксиду вуглецю, що підігрівається знизу, і спостерігається поблизу нижньої межі шару. Описано порядок проведення надкритичної флюїдної екстракції діоксидом вуглецю, при якому концентрація комплексів ізотопу ${ }^{235} \mathrm{U}$ у надкритичному флюїді буде вище природної. 